Primljen / Received: 21.12.2017.

Ispravljen / Corrected: 4.5.2018.

Prihvaćen / Accepted: 15.6.2018.

Dostupno online / Available online: 10.9.2018.

\section{Investigation on the usability of pumice as fibre in stone mastic asphalt}

Author:

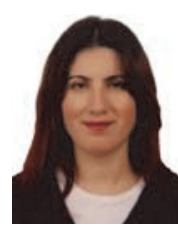

Assist.Prof. Sevil Kofteci, PhD. CE Akdeniz University

Faculty of Engineering

Department of Civil Engineering

Antalya, Turkey

skofteci@akdeniz.edu.tr
Sevil Köfteci

Investigation on the usability of pumice as mineral fibre in stone mastic asphalt

The stone mastic asphalt (SMA) is a type of asphalt surfacing for pavement structures that is normally used on roads destined to heavy vehicle traffic. Because SMA is a gap-graded hot mix asphalt, fibres should be used in order to prevent draining of bitumen between aggregate grains. Two types of fibres are used in SMA: cellulose fibres and mineral fibres. The paper investigates the usability of pumice as mineral fibre in SMA mixes. The obtained results show that pumice can be used in an appropriate proportion (4\%) as an alternative to cellulose fibres in SMA mixes.

Key words:

asphalt pavement, stone mastic asphalt, pumice, stabilizing fibre, Schellenberg test

Prethodno priopćenje

Sevil Köfteci

Istraživanje primjenjivosti plovućca kao mineralnog vlakna u splitmastiks asfaltu

Splitmastiks asfalt (SMA) vrsta je asfaltnog zastora kolničkih konstrukcija koji se u pravilu upotrebljava na cestama namijenjenim teškom prometnom opterećenju. Kako je SMA vruća asfaltna mješavina diskontinuiranog sastava, u mješavini se koriste vlakna da bi se spriječilo ocjeđivanje bitumenskog veziva sa zrna agregata. SMA mješavine koriste dvije vrste vlakana: celulozna vlakna i mineralna vlakna. U radu se analizira mogućnost primjene plovućca kao mineralnog vlakna u mješavinama SMA. Dobiveni rezultati pokazuju da se plovućac može u odgovarajućem omjeru (4\%) koristiti kao zamjena za celulozna vlakna u mješavinama SMA.

Ključne riječi:

asfaltni kolnik, splitmastiks asfalt, plovućac, stabilizirajuće vlakno, Schellenbergovo ispitivanje

Vorherige Mitteilung

Sevil Köfteci

Untersuchung der Anwendbarkeit von Bims als Mineralfaser im Splittmastixasphalt

Splittmastixasphalt (SMA) ist eine Art des Asphaltbelags für Fahrbahnkonstruktionen, der in der Regel für Straßen verwendet wird, die für eine hohe Verkehrsbelastung bestimmt sind. Da SMA eine heiße Asphaltmischung mit einer diskontinuierlichen Zusammensetzung ist, werden in der Mischung Fasern verwendet, um das Ablassen des Bitumenbindemittels von den Aggregatkörnern zu verhindern. In den Mischungen des SMA werden zwei Faserarten verwendet: Zellulosefasern und Mineralfasern. In der Abhandlung wird die Möglichkeit der Anwendung von Bims als Mineralfaser in den Mischungen des SMA analysiert. Die erhaltenen Ergebnisse zeigen, dass Bims in einem entsprechenden Verhältnis (4\%) in den Mischungen des SMA als Ersatz für Zellulosefaser verwendet werden kann.

Schlüsselwörter:

Straßenasphalt, Splittmastixasphalt, Bims, stabilisierende Faser, Schellenberg-Untersuchung 


\section{Introduction}

Transport systems are very important for economic prosperity of all countries. It can generally be stated that highways are the most frequently used transport systems. Highway pavements should be devoid of deformations especially for freight transport. Stone Mastic Asphalt (SMA) was developed in Germany in 1960s in order to obtain a hardwearing material for use on heavily trafficked roads [1, 2]. SMA is a gap-graded HMA (Hot Mix Asphalt) that has been designed to maximize deformation (rutting) resistance and durability by using a structural basis relying on the stone-to-stone contact [3]. This type of grain size distribution is characterized by big gaps owing to the large coarse aggregate content. The large coarse aggregate fraction ensures rutting resistance through stoneto-stone contact, while the high binder content (typically $5.5-7.0 \%$ by weight of mixture) provides durability through an increased film thickness around aggregate particles [4]. The stabilizing additives act here as binder carriers. They should stabilize the high binder content needed for the mastic-like mortar composition during various working phases, i.e. mixing, transporting, paving, and compacting. In this way they prevent the binder from draining off the minerals [5]. Under high temperatures and heavy loading, a harder asphalt grade will also be convenient. The binder modified with a polymer (such as EVA or SBS) may be used to substitute fibrous material [6]. Generally, cellulose and mineral based fibres are used in order to prevent draining in SMA $[7,8]$. However, because the costs associated with the cellulose-based fibres are rather high, the use of various types of fibres or additives is very important, and various experimental studies were performed about this topic [9-11]. Pumice is a porous type of rock that is abundant in Turkey. Therefore, it is relatively cheap. This study aims to investigate and compare the effects of pumice, used as mineral fibre, on SMA properties. Two methods can be used to determine the drain-down amount. The first method is the Schellenberg test. This test generally involves the use of beakers. The second method is the wire basket test. Draining property of SMA mixtures was determined by means of wire baskets fabricated using standard $6.3 \mathrm{~mm}$ sieve cloth.
Cellulose fibres were used for preparing control samples. Pure bitumen was used for preparing samples. Marshall samples were prepared in order to analyse gaps between aggregates for mixtures with an optimum fibre content. Additionally, ITSR (Indirect tensile strength ratio) values were calculated to determine water sensitivity of samples and the results were compared with specification limits.

\section{Experimental studies}

\subsection{Materials}

The experimental studies were carried out in the Road Pavement Research Laboratory of the Akdeniz University in Antalya / TURKEY. 50/70 penetration bitumen was used for the experimental study. In Antalya, 50/70 bitumen is usually used in road construction. For this reason, 50/70 bitumen type was chosen for the study. The basalts used in the study as coarse and fine aggregates were obtained from Kütahya, Turkey. SMA mixtures were designed using the grading curve shown in Figure 1.

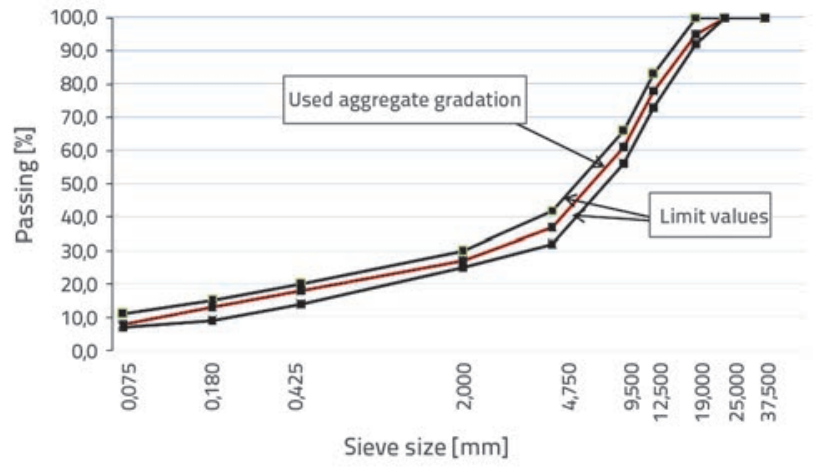

Figure 1. Grading curve of aggregates used in the study

The SMA mixture composition prepared and evaluated for this study was stone mastic asphalt for binder course. Samples were prepared according to Specification [12]. The SMA design criteria are shown in Table 1.

Table 1. Stone mastic asphalt design values and specifications

\begin{tabular}{|l|c|c|}
\hline Features & Binder course & Specification \\
\hline The number of blows to be applied making briquettes & 50 & TS EN 12697-30 \\
\hline Air voids [\%] & $3-4$ & TS EN 12697-8 \\
\hline Voids between mineral aggregates, (VMA) \% min. & 13 & TS EN 12697-8 \\
\hline Bitumen binder, [\%] min. & 5.2 & TS EN 12697-1 \\
\hline Schellenberg drain down test, [\%] max. & 0.3 & TS EN 12697-18 \\
\hline Indirect tensile strength ratio, [\%] min. & 80 & AASHTO T 283 \\
\hline Wheel tracking deformation, 30.000 cycle, $60^{\circ}$ C [\%] max. & 6 & TS EN 12697-22 \\
\hline
\end{tabular}




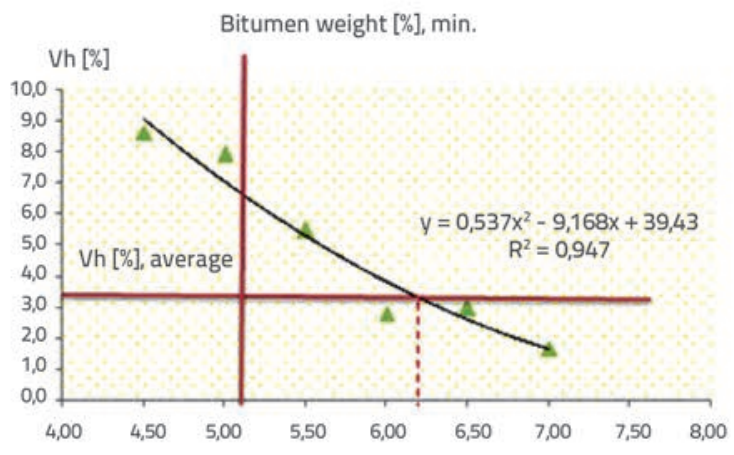

Figure 2. Vh and VMA graphs according to the increasing bitumen $\%$

Basalt has a very hard structure, therefore, it is very difficult to break basalt aggregate. Additionally, according to the methylene blue test, methylene blue value of basalt aggregate was determined as $3 \mathrm{~g} / \mathrm{kg}$. This means that clay rate of basalt aggregates is very high. For this reason, limestone aggregate was used as filler in the study rather than basalt. Limestones were obtained from Antalya, Turkey. The Marshall mix design method was used in experimental studies.

The Marshall mix design method was used in experimental studies .Marshall samples were prepared according to the AASHTO T 245-97 and optimum bitumen rate (OBR) was calculated by using an emperical equation based on aggregate properties [13]. OBR value was calculated as $6.45 \%$ by using Equation 1:

$\mathrm{OBR}=3.25\left[\frac{2.65}{\mathrm{SG}_{\mathrm{agg}}}\right] \sum^{0.2} \mathrm{SSA}$

where $\mathrm{SG}_{\text {agg }}$ is apparent specific gravity of aggregate blend, SSA is specific surface area.

Pumice was obtained from Isparta. It was crushed in the laboratory to two different grain sizes. The grading of the first experimental group ranged from $0180 \mathrm{~mm}$ to $0.075 \mathrm{~mm}$. The second group consisted of grains smaller than $0.075 \mathrm{~mm}$. Pumice material properties were analysed with XRF (X-Ray Fluorescence) and Scanning Electron Microscope (SEM). The XRF test was performed to determine minerals forming pumice and individual proportions of these minerals. The XRF test results are shown in Table 2.

Pumice is a porous type of rock that is often encountered in Turkey. Therefore, it is relatively cheap. Figure 3 illustrates the SEM images for pumice used in the study. The porous structure of pumice can easily be seen in this figure. Because

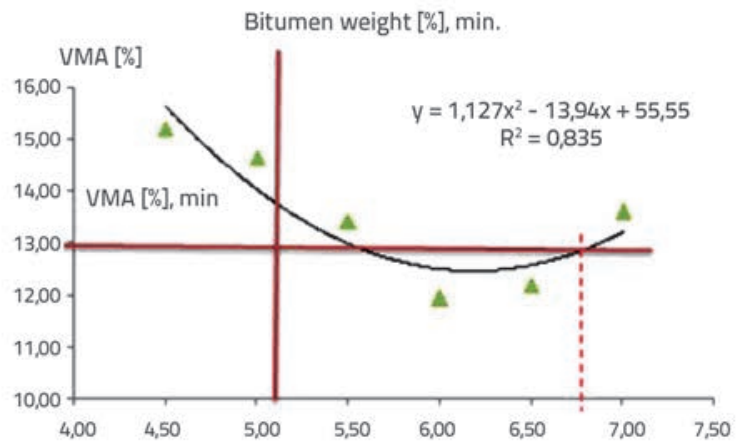

of this feature, pumice is used to incarcerate bitumen between aggregates.

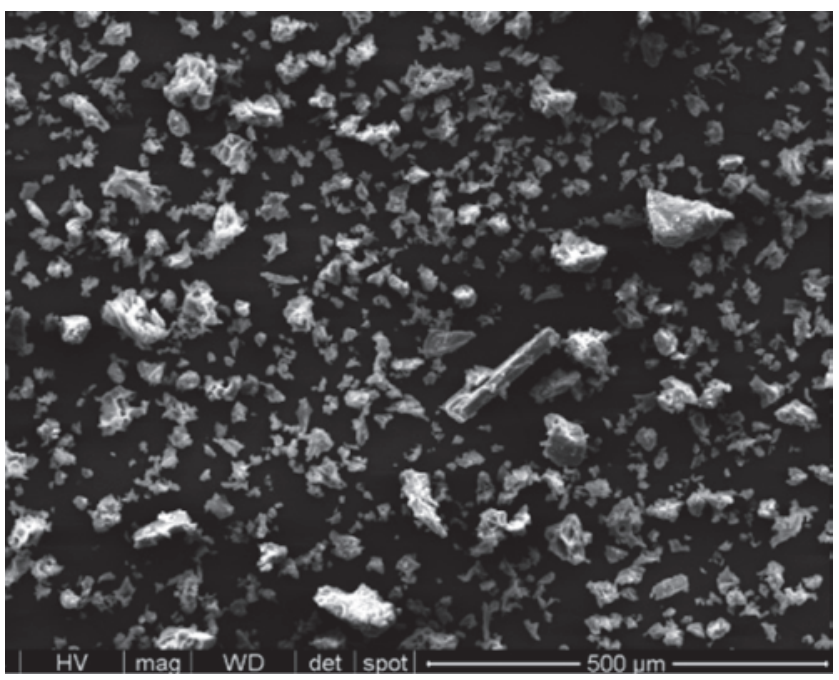

Figure 3. Pumice image observed by SEM

\subsection{Schellenberg / Von Weppen drainage test}

Schellenberg / Von Weppen drainage test was performed in order to determine the drain-down effect of bitumen. This test is generally performed for cellulose-based fibres and is well known in literature. In this study, the drainage preventing capacity of pumice fibre was measured. The properties of this fibre mainly depend on its origin. This fibre is not a commercial product. Additionally, this mineral-based fibre can be found easily and is very inexpensive.

Individual phases of the experiment are shown in Figure 4. The test is conducted as follows [14]. The quantity of $1000 \mathrm{~g}$. $\left(\mathrm{W}_{1}\right)$ of stone mastic mixture was prepared according to the above

Table 2. XRF test result

\begin{tabular}{|c|c|c|c|c|c|c|c|c|c|c|c|c|c|c|c|}
\hline & $\begin{array}{c}\mathrm{SiO}_{2} \\
{[\%]}\end{array}$ & $\begin{array}{c}\mathrm{Al}_{2} \mathrm{O}_{3} \\
{[\%]}\end{array}$ & $\begin{array}{c}\mathrm{Fe}_{2} \mathrm{O}_{3} \\
{[\%]}\end{array}$ & $\begin{array}{c}\mathrm{MgO} \\
{[\%]}\end{array}$ & $\begin{array}{c}\mathrm{CaO} \\
{[\%]}\end{array}$ & $\begin{array}{c}\mathrm{Na}_{2} \mathrm{O} \\
{[\%]}\end{array}$ & $\begin{array}{c}\mathrm{K}_{2} \mathrm{O} \\
{[\%]}\end{array}$ & $\begin{array}{c}\mathrm{TiO}_{2} \\
{[\%]}\end{array}$ & $\begin{array}{c}\mathrm{P}_{2} \mathrm{O}_{5} \\
{[\%]}\end{array}$ & $\begin{array}{c}\mathrm{MnO} \\
{[\%]}\end{array}$ & $\begin{array}{c}\mathrm{Cr}_{2} \mathrm{O}_{3} \\
{[\%]}\end{array}$ & $\begin{array}{c}\mathrm{SO}_{3} \\
{[\%]}\end{array}$ & $\begin{array}{c}\mathrm{LOI} \\
{[\%]}\end{array}$ & $\begin{array}{c}\mathrm{A}_{1} \mathrm{Za} \\
{[\%]}\end{array}$ & $\begin{array}{c}\mathrm{Total} \\
{[\%]}\end{array}$ \\
\hline Pumice & 60.94 & 15.26 & 3.16 & 0.57 & 3.24 & 4.56 & 6.21 & 0.36 & 0.23 & 0.10 & 0.02 & 0.43 & 3.77 & - & 99.70 \\
\hline
\end{tabular}


shown grading curve. The beaker was heated in an oven to 110

${ }^{\circ} \mathrm{C}$ for 15 minutes.

1. Aggregates were put in a heated beaker (Figure 4a).

2. The beaker was placed in an oven at $170{ }^{\circ} \mathrm{C}$ for $60 \pm 1$ minutes.

3. The beaker was removed from the oven and emptied (Figure 4b).

4. The weight of the cooled mixture $\left(W_{2}\right)$ was measured to an accuracy of $0,1 \mathrm{~g}$. (Figure 4c)

5. The drain-down ratio (DR) was calculated using the following equation (2):

$$
D R=100 \times \frac{W_{1}-W_{2}}{W_{1}}
$$
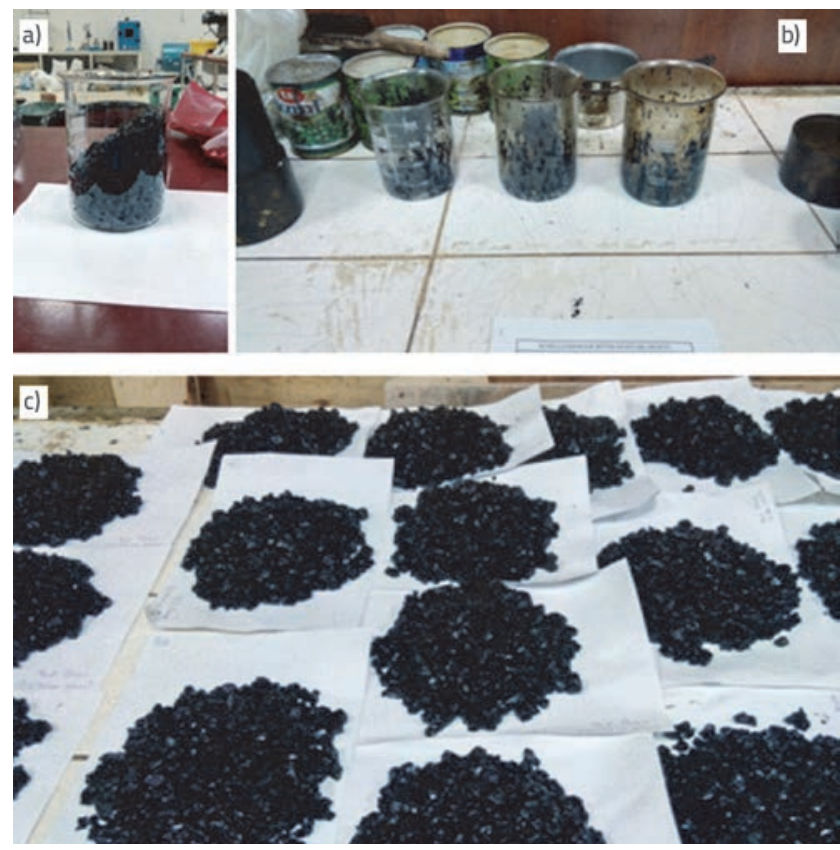

Figure 4. Phases of Schellenberg test

\subsection{Wire basket drainage test}

The wire basket test is the second method used in the study to determine the drain down potential of bitumen. This test was developed by AASHTO T305, 2014 [15]. By using this test, drainage properties of bituminous mixtures were observed during the production, storage, transport, and placement [16]. Figure 5 shows the materials used in the experiment. The above mentioned uncompacted mixtures were prepared and placed in a wire basket fabricated using a standard $6.3 \mathrm{~mm}$ sieve cloth (Figure 5.a). The wire baskets were positioned on the plates whose weight was measured before the test $\left(W_{1}\right)$. Both baskets and plates were placed in an oven for three hours at $170{ }^{\circ} \mathrm{C}$. After three hours, wire baskets and plates were removed from the oven (Figure 5.b). The weight of plates was measured $\left(\mathrm{W}_{2}\right)$. The drain-down ratio (DR) was calculated using Eq. 2
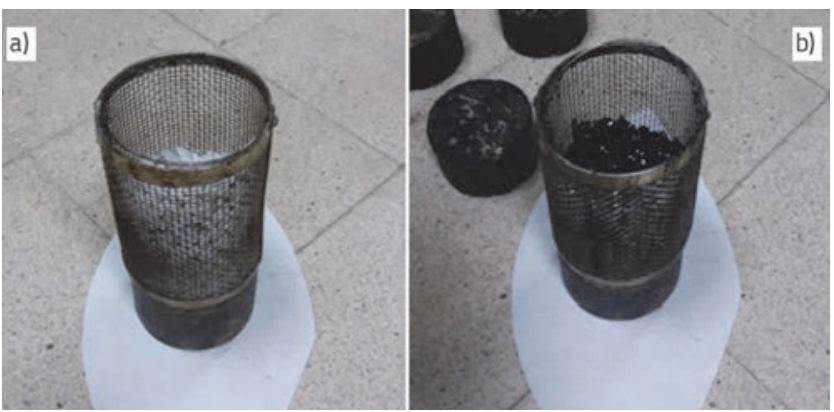

Figure 5. Wire basket test apparatus

\subsection{Determination of air voids and voids between mineral aggregates}

In order to ensure respect of design criteria for SMA, air voids and voids between mineral aggregates (VMA) were determined using Marshall samples. According to results obtained by both drainage tests, $4 \%$ pumice exhibited the best performance with regard to bitumen drainage prevention. Samples with the $6 \%$ additive content exhibited some problems related to the mixing process. For this reason, Marshall samples were prepared with $4 \%$ of pumice fibre and with $6.5 \%$ of optimum bitumen content. 0.25 $\%$ of cellulosic fibre was used in control mixtures, which is the quantity recommended by the manufacturer. Marshall samples (cylinders $102 \mathrm{~mm}$ in diameter and $64 \mathrm{~mm}$ in height) were prepared with basalt aggregates $1150 \mathrm{~g}$ in weight, and $50 / 70$ penetration bitumen. The Marshall sample is shown in Figure 6.

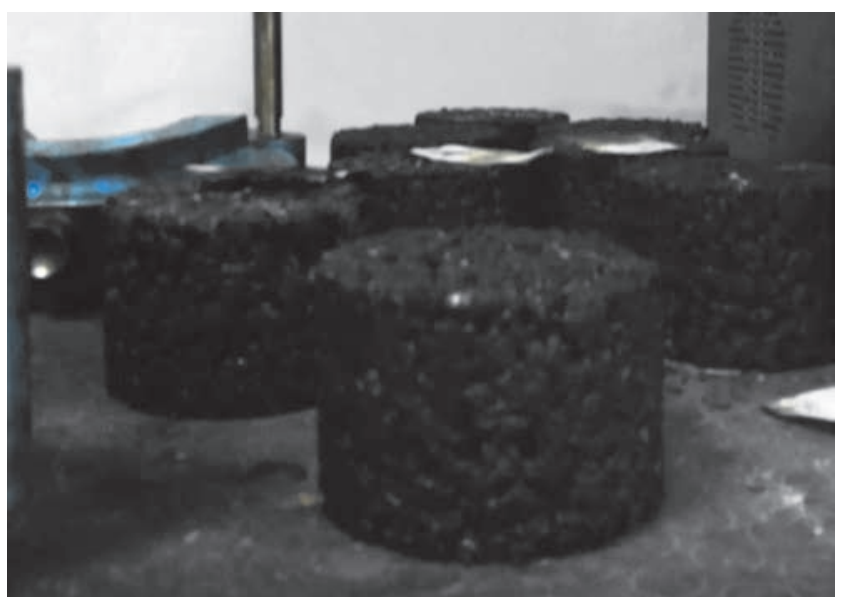

Figure 6. Marshall samples prepared for experimental study

Marshall samples were obtained as described in AASHTO T 245-97, 2015. Basalt and limestone aggregates as per specifications were mixed according to the gradation curve shown in Figure 1. Prepared aggregate mixtures were heated to approximately $170{ }^{\circ} \mathrm{C}$. Then the heated bitumen and aggregates were poured into the mixer tank and mixed for 
120 seconds. The temperature of mixture must be no less than $145{ }^{\circ} \mathrm{C}$ according to Turkish Highway Specifications. To ensure compliance with this condition during the mixing process, the mix temperature was measured by means of an infrared thermometer. After the mixing process, the aggregate and bitumen mixtures were poured into heated steel moulds and compacted with Marshall hammer. The next day, after the moulds have cooled down and mixtures hardened, the samples were removed from steel moulds. The weight of each sample in the air and water was measured. Heights and saturated surface weight values were also measured. The volume, volume specific gravity, and maximum theoretical specific gravity, air voids, and voids between mineral aggregates values, were calculated.

\subsection{Water sensitivity test}

The Indirect Tensile Strength Ratio (ITSR) test is generally performed for asphalt mixtures in order to determine water sensitivity of samples. Water susceptibility is very important for asphalt pavements, especially for stone mastic asphalts due to their gap-graded grain size distribution. In this study, the distribution of recommended new fibres in the mixture strongly affects mixing activities and therefore water sensitivity. In this test, performed according to AASHTO T 283, samples were grouped into two categories: conditional and unconditional. Conditional samples were saturated with water in vacuum desiccators by using vibration at the levels ranging from 50 to $80 \%$. Then they were frozen at $-18{ }^{\circ} \mathrm{C}$ for 16 hours. After 16 hours, conditional samples were immersed in water heated to $60{ }^{\circ} \mathrm{C}$. After 24 hours, both conditional and unconditional samples were immersed into water heated to $25^{\circ} \mathrm{C}$ for 2 hours. Finally, all samples were broken vertically at a loading rate of just about 51 $\mathrm{mm} / \mathrm{min}$ with Marshall Tester. The Indirect Tensile Ratio was calculated by means of Eq. 3

$I T S R=\frac{S_{t 2}}{S_{t 1}}$

where $S_{t 1}$ and $S_{t 2}$ are arithmetic means of indirect tensile strength values of unconditional and conditional samples, respectively.

\section{Results}

\subsection{Schellenberg test results}

Two forms of pumice $(0.180-0.075 \mathrm{~mm})$ and $(<75 \mu)$ were used in the study in order to understand the effect of fibre size. The pumice additive was added to the mixture in the amount of $2 \%$, $4 \%$ and $6 \%$. Drain-down test results of control samples (with bitumen coated cellulose fibre pellets), samples without fibre, and two types of samples with different pumice fibre size, can be seen in Figure 7.

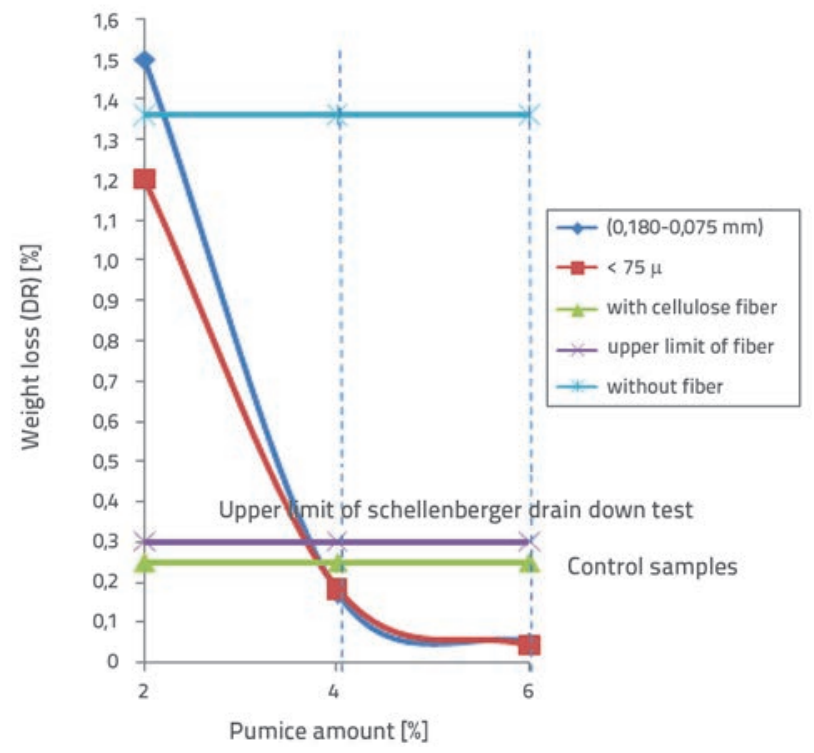

Figure 7. Graph of Schellenberg test results

It can be seen in Figure 7 that drain-down test results were not affected by the size of pumice fibres. The results were very similar to one another, especially in the proportions of 4 $\%$ and $6 \%$. The DR value for samples without fibres amounted $1.36 \%$. This was expected since the bitumen easily flowed through the aggregates without fibres. The DR value for samples with cellulose fibres amounted to $0.25 \%$. Because cellulose fibres were used in the mixture, bitumen did not drain between aggregates. This means that by using cellulose fibres bitumen was actually incarcerated between aggregates. The DR values for $4 \%$ and $6 \%$ of fibres amounted to $0.16 \%$ and $0.18 \%$, respectively. According to SMA design criteria, the DR value should not exceed $0.3 \%$. Samples with pumice fibres proportioned at $4 \%$ and $6 \%$ were provided this condition. However, experimental studies showed that workability of the mixture decreased considerably, especially during the mixing process when the additive ratio was raised as $6 \%$, and that the amount of bitumen surrounding the aggregates decreased as well. On the other hand, the amount of bitumen needed to form the mixture increased. For this reason, experimental studies were continued with $4 \%$ of fibre content. In Schellenberg test, the experiment with the $6 \%$ of additive content was performed in order to fully understand the effect of pumice amount as a fibre in SMA.

\subsection{Wire basket test results}

Due to the fact that many beakers require cleaning process with trichloroethylene in Schellenberger test, the author considers that it would be easier to implement this test 
method to measure drain down capacity. Wire baskets can easily be cleaned. Two grain sizes of pumice fibres were used in this test as well. The obtained results are shown in Figure 8. The weight loss percentages were higher compared to Schellenberg test results. It was expected because of apparatus used in the tests. Just like in the other drainage test, test results show that pumice fibre size had practically no effect on drainage for samples containing $4 \%$ and $6 \%$ of fibres. For reasons explained above, Marshall samples were prepared with $4 \%$ of fibres.

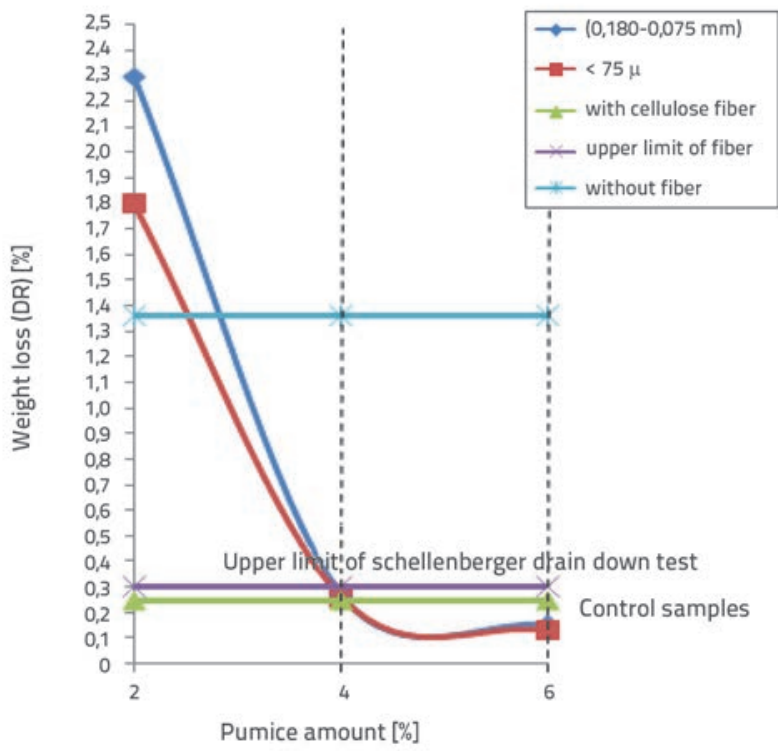

Figure 8. Graph of wire basket test results

\subsection{Determination of air voids and voids in mineral aggregates}

Because of decreased workability and increased amount of bitumen in the mixture during the mixing process, the amount of pumice fibres in the mixture was restricted to $4 \%$. Marshall samples were prepared to control gaps between aggregates. Air voids and voids in mineral aggregates were determined by using these samples. According to Figure 9, air void values, as well as voids in mineral aggregates, increased with pumice fibre additive. This was expected since the amount of pumice fibre is

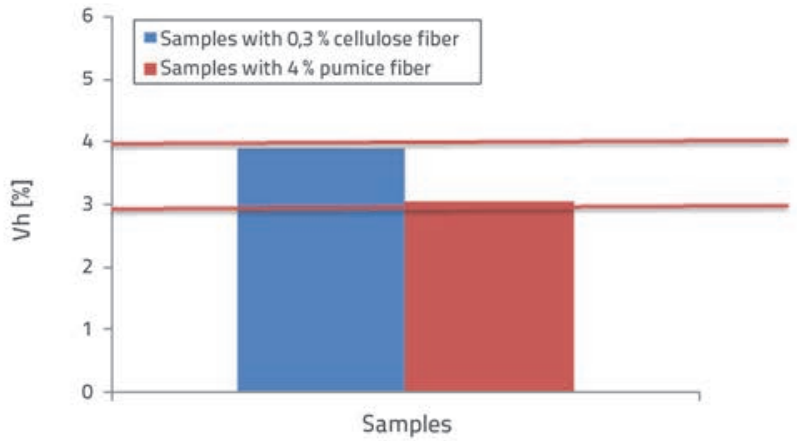

Figure 9. $\mathrm{V}_{\mathrm{h}}$ and VMA values of Marshall samples greater than that of the cellulose fibre. It is believed that pumice fibres filled the gaps between the aggregates.

Additionally, according to Turkish Highway Construction Specifications 2013, the air void volume (Vh) value should be within the range of $3 \%$ to $4 \%$, while the voids in mineral aggregate (VMA) value should be no less than $13 \%$ for the binder course of SMA. The Vh graphic obtained from Marshall samples and given in Figure 9 shows that $V h$ values are situated between the required specification ranges. It can be seen in Figure 9 that VMA values comply with specification limits as well. This means that the pumice fibre rate used in the testing does not adversely affect the mixture in terms of gaps between aggregates.

\subsection{Water sensitivity test results}

Water sensitivity of additive was determined according to ITSR values, as shown in Figure 10. According to the Turkish Highway Construction Specification 2013, the ITSR value should be no less than $80 \%$.

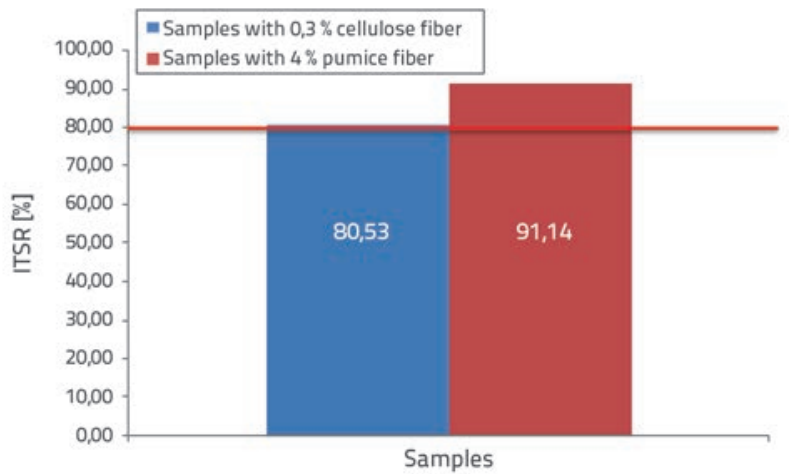

Figure 10. ITSR values obtained from water sensitivity test

As can be seen in Figure10, all samples satisfy this requirement. However, samples with pumice fibres exhibit greater strength against moisture damage. So, when the ITSR values are examined, it can be seen that pumice fibres improve the ITSR values of the mixtures. This conclusion is supported by increased Vh and VMA values. Pumice grains filled gaps between the aggregates. Because of gaps filled with pumice,

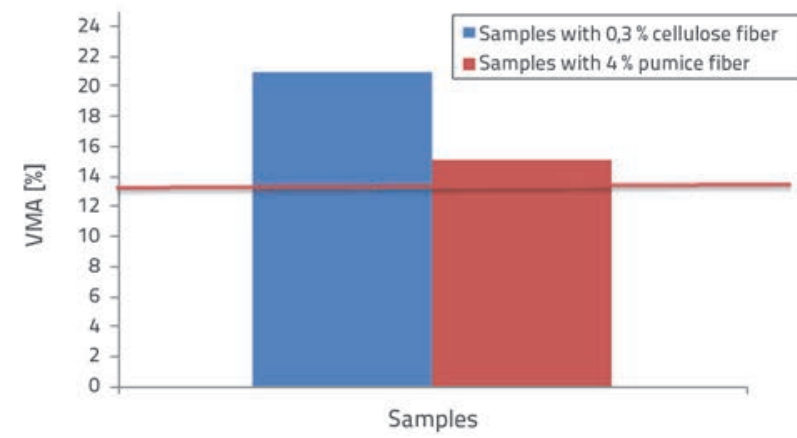


frozen and suddenly melted water did not cause damage to the gaps. This situation increased the strength of samples against vertical axial loads.

\section{Conclusion}

The utility of pumice as fibre in SMA was investigated in this study. In order to determine the drain-down effect of bitumen, Schellenberg tests and wire basket tests were performed for SMA mixtures with the fibre content of 2, 4, and 6 percent, and for control mixtures. Mixtures with the fibres in the amount of $4 \%$ and $6 \%$ proved to be compliant with specification limits. However, when the proportion of additive was $6 \%$, the workability of the mixture decreased and bitumen consumption increased. For this reason, Marshall samples were prepared for the additive ratio of 4 $\%$ only. Marshall samples were prepared so as to determine $V_{h}$ and VMA values for controlling suitability of gaps between aggregates. The samples were grouped into two categories. The cellulose and pumice fibres were added into the first and second group of samples, respectively. $V_{h}$ and VMA values were determined and results were compared with specification limits. $V_{h}$ and VMA values complied with specification limits according to Turkish Highway Construction Specifications 2013. Water sensitivity test results showed that pumice fibres improved the ITRS values of samples, because pumice grains filled gaps between aggregates. Structural properties of pumice porous structure were investigated and evaluated using the scanning electron microscope. Preliminary tests results indicate that pumice in the amount $4 \%$ in the SMA mixture could provide for an optimized performance of flexible pavements.

\section{Acknowledgments}

This research was sponsored by the BAP (Scientific Research Projects Coordination Unit of Akdeniz University, Turkey) under the project code: FYL-2015-752.

\section{REFERENCES}

[1] Khodaii, A., Haghshenas, H.F., Tehrani, H.K., Khedmati, M.: Application of Response Surface Methodology to Evaluate Stone Matrix Asphalt Stripping Potential, KSCE Journal of Civil Engineering, 17 (2013) 1, pp. 117-121.

[2] Woodward, D., Millar, P., Lantieri, C., Sangiorgi, C., Vignali, V.:"The wear of Stone Mastic Asphalt due to slow speed high stress simulated laboratory trafficking, Construction and Building Materials, 110 (2016), pp. 270-277, https://doi.org/10.1016/j. conbuildmat.2016.02.031

[3] Pavement Interactive, Information on http://www. pavementinteractive.org /article/stone-matrix-asphalt, Date of Access: 10.11.2016, Subject: Stone mastic asphalt

[4] Putman, B.J., Amirkhanian, S.N.: Utilization of waste fibres in stone matrix asphalt mixtures, Resources, Conservation and Recycling, 42 (2004), pp. 265-274, https://doi.org/10.1016/j. resconrec.2004.04.005

[5] Drüschiner, L., Schafer, V.: Stone Mastic Asphalt Guide, German Asphalt Association, pp. 5-8, 2000.

[6] Chiu, C., Lu., L.: A laboratory study on stone matrix asphalt using ground tire rubber, Construction and Building Materials; 21 (2007), pp. 1027-1033, https://doi.org/10.1016/j. conbuildmat.2006.02.005

[7] Oda, S., Fernandes J.R., Ildefenso, J.S.: Analysis of use of natural fibres and asphalt rubber binder in discontinuous asphalt mixtures, Construction and Building Materials, 26 (2012), pp.1320.

[8] Yadykina, V., Tobolenko, S., Trautvain, A., Zhukova, A.: The Influence of Stabilizing Additives on Physical and Mechanical Properties of Stone Mastic Asphalt Concrete, Procedia Engineering, 117 (2015)، pp. 376 - 381, https://doi.org/10.1016/j.proeng.2015.08.181
[9] Sengul, C.E., Oruc, S., Iskender, E., Aksoy, A.: Evaluation of SBS modified stone mastic asphalt pavement performance, Construction and Building Materials, 41 (2013), pp. 777-783, https://doi.org/10.1016/j.conbuildmat.2012.12.065

[10] Herraiz, T.R., Herraiz, J.I.R., Domingo, L.M., Domingo, F.C.: Posidonia oceanica used as a new natural fibre to enhance the performance of asphalt mixtures, Construction and Building Materials, 102 (2016), pp. 601-612, https://doi.org/10.1016/j. conbuildmat.2015.10.193

[11] Manosalvas-Parades, M., Gallego, J., Saiz, L., Bermejo, J.M.: Modified binders an an alternative to cellulose fibre-SBS polymers in Stone Mastic Asphalt, Construction and Building Materials, 121 (2016), pp. 727-732, https://doi.org/10.1016/j. conbuildmat.2016.06.028

[12] General Directorate of Highways, Highway Construction Specifications, Ankara, Turkey, General Directorate of Highway Press, 2013 (in Turkish).

[13] Setyawan, A.: Design and properties of hot mixture porous asphalt for semi-flexible pavement application, Media Teknik Sıpıl, 5 (2005) 2, pp. 41-45

[14] Blazejowski, K.: Stone Mastic Asphalt: Theory and Practice, CRC Press, Taylor \& Francis Group, USA, 2011.

[15] AASHTO T305, Standard Method of Test for Determination of drain down Characteristics in Uncompacted Asphalt Mixtures, American Association of State Highway and Transport Officials, 2014.

[16] Bindu, C.S., Beena, K.S.: Influence of Additives on the Drain Down Characteristics of Stone Mastic Asphalt Mixtures, IJRET: International Journal of Research in Engineering and Technology, 3 (2014), pp. 83-88, https://doi.org/10.15623/ijret.2014.0307014 